\title{
Genetic Analysis of Plant Pathogenic Bacteria in the Genus Clavibacter Using Allozyme Electrophoresis
}

\author{
By IAN T. RILEY, ${ }^{*} \dagger$ TERRY B. REARDON ${ }^{2}$ AND ALAN C. MCKAY ${ }^{1}$ \\ ${ }^{1}$ Plant Pathology Unit, South Australian Department of Agriculture, Waite Agricultural Research \\ Institute, Glen Osmond, South Australia 5064, Australia \\ ${ }^{2}$ Evolutionary Biology Unit, South Australian Museum, North Terrace, Adelaide, \\ South Australia 5000, Australia
}

(Received 26 April 1988; revised 5 August 1988)

\begin{abstract}
Allozyme electrophoresis was used to examine the relationships among species of Clavibacter, a genus of bacteria mostly causing gummosis in various graminaceous hosts. Allelic profiles were determined at 20 enzyme loci for 28 strains representing $C$. iranicum, $C$. rathayi, $C$. tritici, three subspecies of $C$. michiganense, Clavibacter sp. from Lolium rigidum, and 'Corynebacterium agropyri'. The genetic differences between species were at least $70 \%$ and between strains within a species up to $35 \%$ except for the subspecies of $C$. michiganense, which differed by up to $75 \%$. The implications of these results for the classification of these Clavibacter spp. is discussed.
\end{abstract}

\section{INTRODUCTION}

The genus Clavibacter Davis, Gillaspie, Vidaver and Harris 1984 contains plant pathogenic coryneform bacteria characterized by the presence of 2,4-diaminobutyric acid as a cell wall component (Davis et al., 1984; Riley 1987). Within this genus there is a group of species which produce distinctive infections of grasses: Clavibacter iranicum (Carlson and Vidaver 1982) Davis, Gillaspie, Vidaver and Harris 1984 and Clavibacter tritici (Carlson and Vidaver 1982) Davis, Gillaspie, Vidaver and Harris 1984 on Triticum spp. L.; Clavibacter rathayi (Smith 1913) Davis, Gillaspie, Vidaver and Harris 1984 on Dactylis glomerata L.; Clavibacter sp. on Lolium rigidum Gaud. The Clavibacter sp. from $L$. rigidum has occasionally been found in other grass species in infected $L$. rigidum pasture (Chatel et al., 1979; Riley, 1987) but for the purposes of this paper will be referred to as Clavibacter sp. ex Lolium. The typical symptom of infection by these pathogens is gummosis of the grass inflorescence before it emerges from the boot. $C$. iranicum, $C$. tritici and Clavibacter sp. ex Lolium require for infection of their hosts nematode vectors in the genus Anguina (Sabet, 1954; Price et al., 1979); the same is likely to be true of the other pathogens, given the similarity of the symptoms and their specific adhesion to Anguina spp. (I. T. Riley \& A. C. McKay, unpublished). 'Corynebacterium agropyri', a bacterium which caused gummosis of Agropyron spp. Gaertn., has recently been reisolated from 30- and 40-year old herbarium specimens (Murray, 1986) and although pathogenicity could not be confirmed, the bacterium does adhere specifically to Anguina spp. (I. T. Riley \& A. C. McKay, unpublished) and does contain 2,4-diaminobutyric acid in its cell walls (T. D. Murray, personal communication), and therefore fits with this group.

The taxonomic relationships within this group of plant pathogens now classified as Clavibacter (Davis et al., 1984) have been examined in a number of studies, and proposed classifications have ranged from classifying each of the pathogens as pathovars of a single species, Clavibacter michiganense (Smith 1910) Davis, Gillaspie, Vidaver and Harris 1984

\footnotetext{
† Present address: Western Australian Department of Agriculture, PO Box 19, Kununurra, Western Australia 6743, Australia.

$0001-4856$ (C) 1988 SGM
} 
through to maintaining each as a distinct species (Bradbury, 1973; Carlson \& Vidaver, 1982; Davies et al., 1984; Dye \& Kemp, 1977; Lazar, 1968; Masuo \& Nakagawa, 1970; Riley, 1987; Sabet, 1954; Seiler, 1983). The nomenclature of Davis et al. (1984), the most recent treatment, has been used in this paper. No single comparative study has included strains of all the pathogens likely to belong to the genus Clavibacter.

The only comparative study including the Clavibacter sp. from $L$. rigidum and hosts associated with infected $L$. rigidum pasture (Riley, 1987) found that, based on serological data, it was quite distinct from $C$. rathayi, the name which has been commonly used for this pathogen on the basis of an inadequate identification without comparison with recognized strains (Bird \& Stynes, 1977). No comparative study that includes 'Corynebacterium agropyri' has been reported. Clarification of the relationship of Clavibacter sp. ex Lolium and 'Corynebacterium agropyri' to the other Clavibacter spp. is still required.

The aim of the work reported here was to examine the genetic relationships among strains in the genus Clavibacter, with particular emphasis on the pathogens causing gummosis of grasses, using allozyme electrophoresis. This technique has been most useful in the resolution of taxonomic problems at the species level in eukaryotic organisms (Richardson et al., 1986). Although the technique has been used in relatively few bacterial studies, Ochman et al. (1983) listed some advantages of multilocus electrophoresis over other methods for measuring genetic variation in bacteria.

\section{METHODS}

The Clavibacter strains used are presented in Table 1; fuller details of these strains were presented by Riley (1987). Each strain was grown on agar slopes (Riley, 1987) for $6 \mathrm{~d}$. The bacterial growth was suspended in $9 \mathrm{ml}$ sterile water and diluted to an optical density of 0.1 at $600 \mathrm{~nm}$. Liquid medium [containing, $\mathrm{g}^{-1}:$ glucose, 10; Casamino acids (Difco), 2; yeast extract (Difco), $2 ; \mathrm{K}_{2} \mathrm{HPO}_{4}, 2 ; \mathrm{MgSO}_{4} .7 \mathrm{H}_{2} \mathrm{O}, 0 \cdot 3$ ], having been autoclaved $\left(121^{\circ} \mathrm{C}, 15 \mathrm{~min}\right)$ before the addition of the glucose, was dispensed into replicate flasks $(50 \mathrm{ml}$ in $250 \mathrm{ml}$ Erlenmeyer flasks) for each strain and inoculated with $1 \mathrm{ml}$ bacterial suspension. The cultures were grown for $48 \mathrm{~h}$ at $25^{\circ} \mathrm{C}$ on an orbital shaker at 200 r.p.m. Cells were harvested by centrifugation to give at least $200 \mu 1$ pellet and were washed three times in sterile $0.02 \mathrm{M}$-phosphate-buffered saline at $5{ }^{\circ} \mathrm{C}$. Excess liquid was removed after centrifugation for $5 \mathrm{~min}$ at $12000 \mathrm{~g}$. An equal volume of cold lysing solution (Richardson et al., 1986) was added to the pellet, and the mixture sonicated in the cold for $15 \mathrm{~s}$ in three bursts of $5 \mathrm{~s}$ each. The homogenates were centrifuged at $4{ }^{\circ} \mathrm{C}$ at $8000 \mathrm{~g}$ for $5 \mathrm{~min}$. The supernatants were dispensed into capillary tubes and stored at $-20^{\circ} \mathrm{C}$ until used for electrophoretic analysis.

Table 1. Clavibacter strains examined using allozyme electrophoresis

Species

Clavibacter iranicum
Clavibacter michiganense
subsp. insidiosum
subsp. michiganense
subsp. nebraskense
Clavibacter rathayi
Clavibacter sp.
ex Lolium (S.A.)
ex Lolium (W.A.)

Clavibacter tritici

'Corynebacterium agropyri'
Laboratory number and source*

CS13, PDDCC $3496^{\mathrm{T}}$

CS20, NCPPB 1109

CS25, NCPPB 2979

CS24, NCPPB $2581^{\mathrm{T}}$

CS5, PDDCC 2571; CS6, PDDCC 2572; CS7, PDDCC 2573; CS15, NCPPB 80; CS18, NCPPB 797; CS26, NCPPB $2980^{\mathrm{T}}$

CS1, A.F. Bird, Manoora; CS2, A.F. Bird, Murray Bridge; CS14, Murray Bridge, 1983; CS33, Port Gawler, 1984; CS34, Wharminda, 1984

CS3, A.F. Bird, Kantanning; CS28, WSM 188; CS29, WSM 454; CS30, WSM 447; CS31, WSM 455; CS32, WSM 456

CS4, PDDCC 2624; CS12, PDDCC 2628; CS16, NCPPB 471; CS17,

NCPPB 255; CS21, NCPPB 1857 ; CS22, NCPPB 1953

CS35, T.D. Murray, CA-1

* PDDCC, Plant Diseases Division Culture Collection, Plant Diseases Division, DSIR, Mt Albert Rd, Private Bag, Auckland, New Zealand; NCPPB, National Collection of Plant Pathogenic Bacteria, Harpenden, UK; WSM, Western Australian Department of Agriculture, Baron-Hay Ct, South Perth, WA 6151, Australia. 
Allozyme electrophoresis was done on Cellogel (Chemetron, Milan) according to the procedures given in Richardson et al. (1986). Electrophoresis on any day used samples thawed on that day. A total of 35 enzymes were stained for, of which 20 gave staining of sufficient intensity and resolution for reliable genetic interpretation. The enzymes scored, with an abbreviation and the Enzyme Commission designation, were adenylate kinase, AK (EC 2.7.4.3); alkaline phosphatase, AP (EC 3.1.3.1); acetylesterase, EST (EC 3.1.1.6); glucose-6-phosphate dehydrogenase, G6PD (EC 1.1.1.49); glucose-phosphate isomerase, GPI (EC 5.3.1.9); aspartate aminotransferase, GOT (EC 2.6.1.1); glutathione reductase, GSR (EC 1.6.4.2); hexokinase, HK (EC 2.7.1.1); isocitrate dehydrogenase, IDH (EC 1.1.1.42); leucine aminopeptidase, LAP (EC 3.4.11.1); mannose-6-phosphate isomerase, MPI (EC 5.3.1.8); purine nucleoside phosphorylase, NP (EC 2.4.2.1); peptidase (phenylalanine proline), PEPD (EC 3.4.13.9); phosphoglycerate kinase, PGK (EC 2.7.2.3); phosphoglycerate mutase, PGAM (EC 5.4.2.1); 6-phosphogluconate dehydrogenase, 6PGD (EC 1.1.1.44); pyruvate kinase, PK (EC 2.7.1 .40); triosephosphate isomerase, TPI (EC 5.3.1.1); UDP-glucose pyrophosphorylase, UGPP (EC 2.7.7.9); uridine monophosphate kinase, UMPK (EC 2.7.4.4). For each pair of strains, the percentage of allelomorphs out of 20 that were different was calculated to yield a difference matrix. This matrix was used to construct a phenogram by average linkage cluster analysis (Sneath \& Sokal, 1973).

\section{RESULTS}

The 28 strains under investigation fell into 14 electrotypes. Table 2 shows the allelic profiles for the 14 electrotypes of Clavibacter strains; the strains within each electrotype had identical profiles for all 20 loci. The strains are grouped into electrotypes A1 to A3 for Clavibacter sp. ex Lolium, B1 to B3 for Clavibacter michiganense, $\mathrm{C}$ for Clavibacter iranicum, D for 'Corynebacterium agropyri', E1 to E3 for Clavibacter rathayi and F1 to F3 for Clavibacter tritici.

The phenogram derived by average linkage cluster analysis from the matrix of percentage differences among the 14 groups of strains is presented in Fig. 1. The differences between electrotypes belonging to different species ranged from $70 \%$ to $95 \%$ and between electrotypes within a species from $5 \%$ to $35 \%$ except for the subspecies of Clavibacter michiganense, which differed by $45 \%$ to $75 \%$.

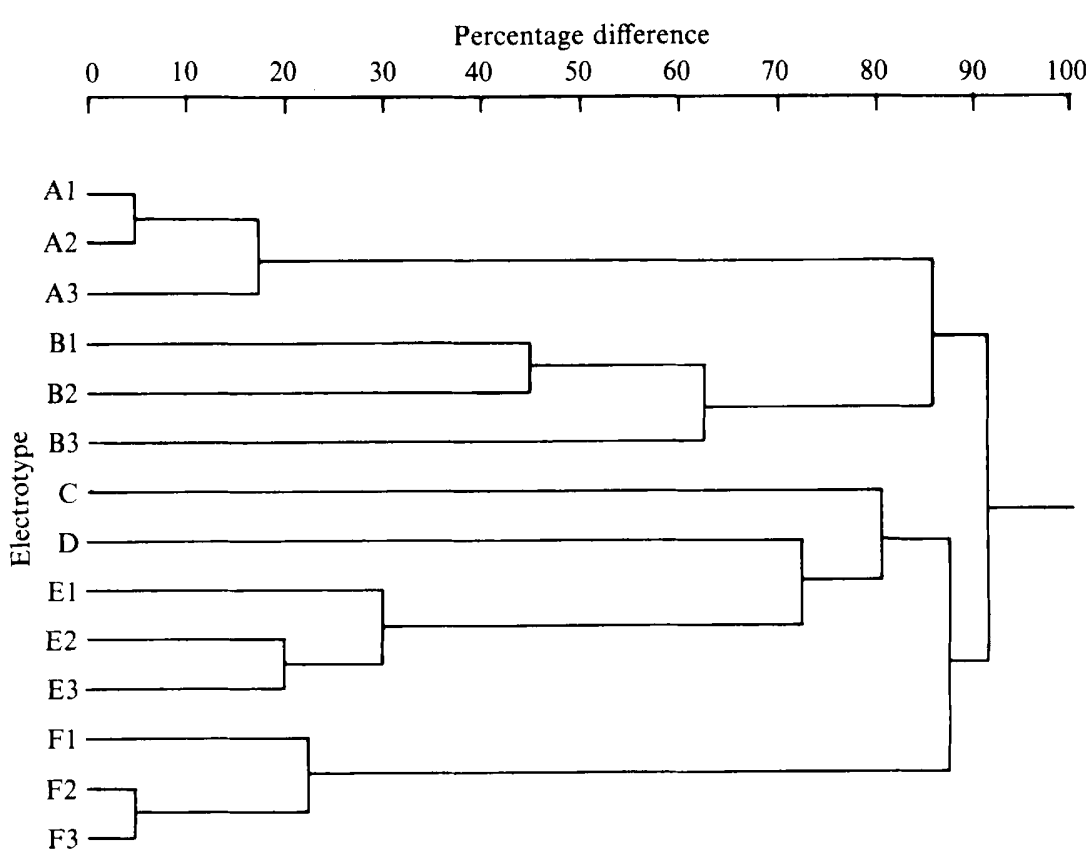

Fig. 1. Phenogram showing relationships among Clavibacter electrotypes based on average linkage cluster analysis of the percentage differences between electrotypes (strains which constitute each electrotype are given in Table 2). 


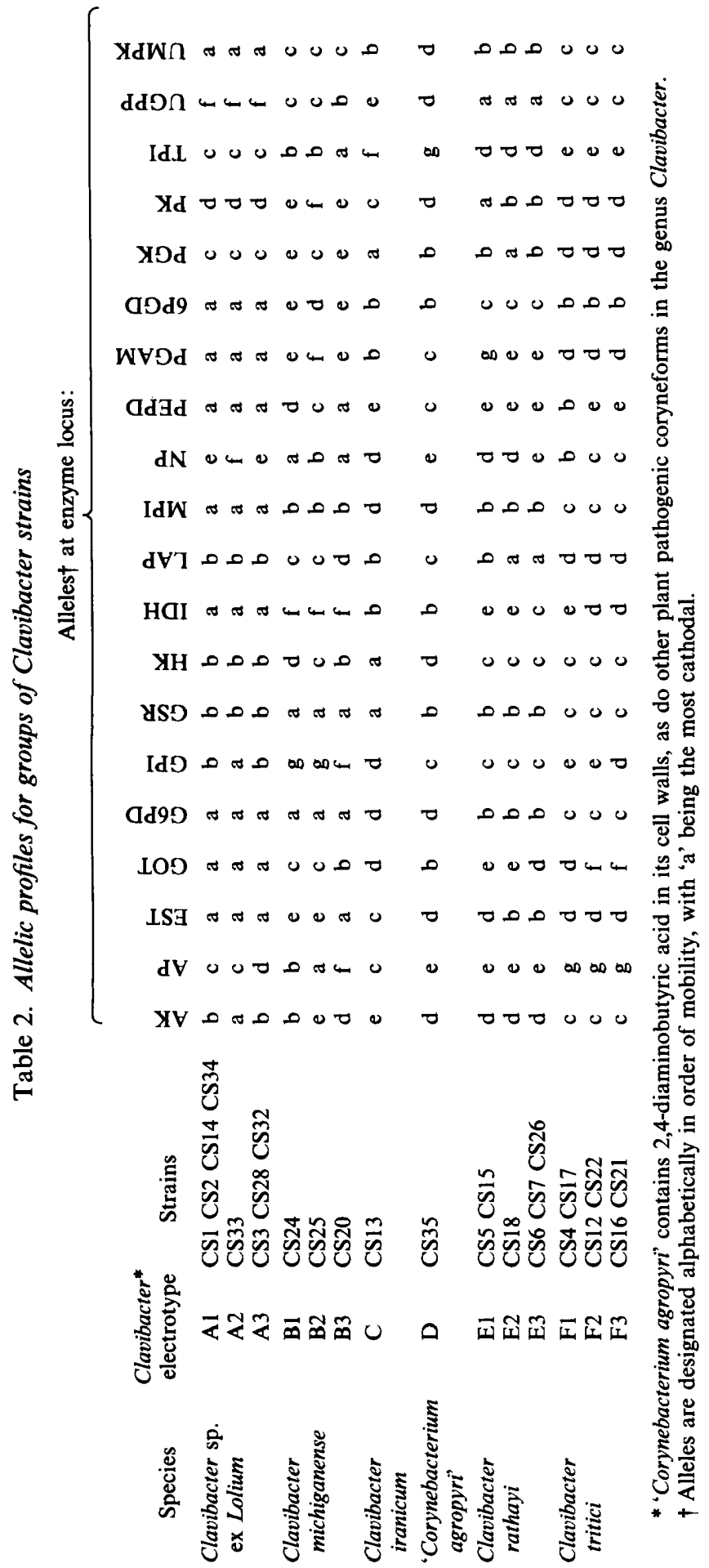


Within Clavibacter sp. ex Lolium there were three electrotypes, A1, A2 and A3. The electrotype A3 consisted solely of strains from Western Australia whereas the South Australian strains fell in two electrotypes, A1 and A2. The Western Australian strains (A3) differed by about $18 \%$ from the South Australian strains (A1 and A2) due to differentiation at three enzyme loci, AK, GPI and NP. The electrotype A2 (consisting of a single strain, CS33) differed by $5 \%$ from the other South Australian strains (A1) due to a single enzyme locus, AP.

The Clavibacter rathayi strains consisted of three electrotypes, E1, E2 and E3, with a maximum difference of $35 \%$. The $C$. rathayi strains CS5 and CS15, from the same original isolation though procured from different culture collections (Table 1), gave identical profiles.

Similarly the Clavibacter tritici strains included three electrotypes, F1, F2 and F3, with a maximum difference of $25 \%$ between pairs. Again two strains, CS4 and CS17, which had originated from the same isolation (Table 1) were in the one electrotype.

Consistent with haploid organisms, no heterozygous phenotypes were observed; however, the enzyme bands produced by the $C$. michiganense strains were diffuse and more difficult to score.

\section{DISCUSSION}

The classification of Clavibacter iranicum, C. tritici, C. rathayi, Clavibacter sp. ex Lolium and 'Corynebacterium agropyri' as distinct species is consistent with the data collected in this study. The differences within each of these species were no more than $35 \%$ but at least $70 \%$ between these species.

The difficulty arises with the Clavibacter michiganense subspecies, which had differences of up to $75 \%$ between $C$. michiganense subsp. insidiosum and $C$. michiganense subsp. michiganense. The C. michiganense subspecies were originally named as separate species but were subsequently considered to be sufficiently similar to be classified as members of one species (Dye \& Kemp, 1977; Carlson \& Vidaver, 1982).

For many higher organisms a large body of data shows that the level of genetic divergence between populations within a species is not normally greater than $15 \%$ and in birds as little as $5 \%$ (Richardson et al., 1986). Significant electrophoretic studies on bacteria have generally shown that what is currently recognized as a single species does contain genetic diversity among strains at the $50 \%$ level or greater (Ochman et al., 1983; Musser et al., 1985; Selander et al., 1985; Reardon et al., 1986). Criteria for delineation of bacterial species based on allelic diversity remain largely subjective but further investigations of this nature may lead to a more objective approach.

Although the results presented here cannot conclusively identify the boundaries between species in the genus Clavibacter, they do have some useful comparative value. For instance, the Clavibacter sp. ex Lolium, which has been frequently called $C$. rathayi on the basis of inadequate identification (Riley, 1987), showed as much difference from $C$. rathayi as $C$. rathayi did from the other named species. Similarly, the cluster analysis would indicate that 'Corynebacterium agropyri' was distinct from the named species. On this basis, it would be reasonable to conclude that both Clavibacter sp. ex Lolium and 'Corynebacterium agropyri' are distinct species, with the distinction being somewhat clouded only by the variation within Clavibacter michiganense. However, a reasonable interpretation of the data presented here is that the three subspecies of $C$. michiganense should be considered distinct species.

Allozyme electrophoresis appears to be a useful tool for strain identification in bacteria. The duplicated strains from different collections (Clavibacter tritici strains CS4 and CS17;C. rathayi strains CS5 and CS15) gave identical allelic profiles. Such a comparison including ATCC 13659, which is supposed to be identical to CS5 and CS15, would be useful because ATCC 13659 has been shown to be atypical of $C$. rathayi. ATCC 13659 has cell wall peptidoglycans based on lysine rather than 2,4-diaminobutyric acid and differing lipid composition (Collins, 1983) as well as being clearly unrelated to other $C$. rathayi strains in the numerical taxonomic study of Seiler (1983). Application of allozyme electrophoresis would resolve this problem.

In most cases where the allelic profiles were identical, the strains had related origins. The electrotype A1 was isolated from South Australia, A3 from Western Australia, E3 from New 
Zealand and F2 from Iran. The only electrotype with strains of diverse origin was F3, with CS16 from India and CS21 from Iran. The correlation of the genetic similarity within a region may indicate the genetic homogeneity of the bacterial populations in a region at the time the strains were isolated or that the strains were collected from a single or closely related sites. The latter is not true for the South Australian strains, which were from widely distributed sites. Allozymic analysis of larger numbers of strains within the range of a particular bacterial species could provide much data on the geographic origins of the species and its history of dispersal.

The difference between the South Australian and Western Australian strains of Clavibacter sp. ex Lolium is worth noting. Studies of the adhesion of these strains to the cuticles of various Anguina spp. (I. T. Riley \& A. C. McKay, unpublished) showed patterns that clearly indicate the genetic divergence or different origins of the populations from these two geographically isolated regions. The genetic differences that have been observed suggest the possibility of ecological differences between populations of Clavibacter sp. ex Lolium. Such ecological diversity would have significance for the management of this toxigenic plant pathogen.

We thank the Australian Meat and Livestock Research and Development Corporation for financial support. J. Gooden and J. Birrell are thanked for their technical assistance. Advice from M. Adams and P. Baverstock during the preparation of the manuscript was appreciated. Importation of bacterial strains was done under permit from the Australian Quarantine Service.

\section{REFERENCES}

BIRD, A. F. \& STYNEs, B. A. (1977). The morphology of a Corynebacterium sp. parasitic on annual rye grass. Phytopathology 67, 828-830.

BRADBURY, J. F. (1973). Corynebacterium rathayi. Commonwealth Mycological Institute Descriptions of Pathogenic Fungi and Bacteria, no. 376. Slough, UK: Commonwealth Agricultural Bureaux.

Carlson, R. R. \& Vidaver, A. K. (1982). Taxonomy of Corynebacterium plant pathogens, including a new pathogen of wheat, based on polyacrylamide gel electrophoresis of cellular proteins. International Journal of Systematic Bacteriology 32, 315-326.

Chatel, D. L., Wise, J. L. \& MARFleEt, R. A. (1979). Ryegrass toxicity organism found on other grasses. Journal of Agriculture - Western Australia 20, 89.

Collins, M. D. (1983). Cell wall peptidoglycan and lipid composition of the phytopathogenic Corynebacterium rathayi (Smith). Systematic and Applied Microbiology 4, 193-198.

Davis, M. J., Gillaspie, A. G., JR, Vidaver, A. K. \& HARRIS, R. W. (1984). Clavibacter: a new genus containing some phytopathogenic coryneform bacteria, including, Clavibacter xyli subsp. xyli sp. nov., subsp. nov. and Clavibacter xyli subsp. cynodontis subsp. nov., pathogens that cause ratoon stunting disease of sugarcane and bermudagrass stunting disease. International Journal of Systematic Bacteriology 34, 107-117

DYE, D. W. \& KEMP, W. J. (1977). A taxonomic study of plant pathogenic Corynebacterium species. New Zealand Journal of Agricultural Research 20, 563-582.

LAZAR, I. (1968). Serological relationships of corynebacteria. Journal of General Microbiology 52, 77-88.

Masuo, E. \& Nakagawa, T. (1970). Numerical classification of bacteria. Part IV. Relationships among some corynebacteria based on serological similarity alone. Agricultural and Biological Chemistry 34, 1375-1382.

MURRAY, T. D. (1986). Isolation of Corynebacterium agropyri from 30 to 40 -year-old herbarium specimens of Agropyron species. Plant Disease 70, 378-380.

Musser, J. M., Granoff, D. M., Pattison, P. E. \& SELANDER, R. K. (1985). A population genetic framework for the study of invasive diseases caused by serotype b strains of Haemophilus influenzae. Proceedings of the National Academy of Sciences of the United States of America 82, 5078-5082.

Ochman, H., Whittam, T. S., Caugant, D. A. \& SelaNDER, R. K. (1983). Enzyme polymorphism and genetic population structure in Escherichia coli and Shigella. Journal of General Microbiology 129, 2715-2726.

Price, P. C., Fisher, J. M. \& KerR, A. (1979). Annual ryegrass toxicity: parasitism of Lolium rigidum by a seed-gall forming nematode (Anguina sp.). Annals of Applied Biology 91, 359-369.

Reardon, T. B., Gibson, A. H., Adams, M. A. \& BAVERSTOCK, P. R. (1986). Genetic diversity among Rhizobium isolates. Proceedings of the Eighth Australian Nitrogen Fixation Conference. Australian Institute of Agricultural Science Occasional Publication no. 25 , p. 59.

Richardson, B. J., BaVerstock, P. R. \& Adams, M. (1986). Allozyme Electrophoresis: a Handbook for Animal Systematics and Population Studies. Sydney: Academic Press Australia.

RILEY, I. T. (1987). Serological relationships between strains of coryneform bacteria responsible for annual ryegrass toxicity and other plant pathogenic corynebacteria. International Journal of Systematic Bacteriology 37, 153-159.

SABET, K. A. (1954). On the host range and systematic position of the bacteria responsible for the yellow slime disease of wheat (Triticum vulgare Vill.) and cocksfoot grass (Dactylis glomerata L.). Annals of Applied Biology 41, 606-611.

SEILER, H. (1983). Identification key for coryneform bacteria derived by numerical taxonomic studies. Journal of General Microbiology 129, 1433-1471.

Selander, R. K. McKinney, R. M., Whittam, T, S., Bibb, W. F., BrenNer, D. J., Notle, F. S. \& Pattison, P. E. (1985). Genetic structure of populations of Legionella pneumophila. Journal of Bacteriology 163, 1021-1037.

SNEATH, P. H. A. \& Sokal, R. R. (1973). Numerical Taxonomy. San Francisco: W. H. Freeman. 